\title{
On the Distinction of Constative and Performative Sentences
}

\author{
Liming Zhang, Jie Han, Jiayi Li \\ College of Foreign Language Education and International Business, Baoding University, Baoding, China \\ Email: zhangdawn@126.com
}

How to cite this paper: Zhang, L. M., Han, J., \& Li, J. Y. (2020). On the Distinction of Constative and Performative Sentences. Open Journal of Modern Linguistics, 10, 828-833.

https://doi.org/10.4236/ojml.2020.106052

Received: November 13, 2020

Accepted: December 12, 2020

Published: December 15, 2020

Copyright $\odot 2020$ by author(s) and Scientific Research Publishing Inc. This work is licensed under the Creative Commons Attribution International License (CC BY 4.0).

http://creativecommons.org/licenses/by/4.0/

\section{(c) (i) Open Access}

\begin{abstract}
J. Austin was the first philosopher and linguist who elaborated the performative function of language, which developed into speech act theory, one of the most important theories of early pragmatics. His elaboration of the performative function begins with the distinction of constative and performative sentences. This article reviews how J. Austin's distinction of constative and performative was formed. It also shows the significance of the distinction for the $20^{\text {th }}$ century philosophy and linguistics.
\end{abstract}

\section{Keywords}

Constative Sentences, Performative, Sentences, Speech Act Theory

\section{The Introduction of Constative and Performative Sentences}

\subsection{The Background}

J. Austin was one of the greatest philosophers in the $20^{\text {th }}$ century. He was a leading member of the "ordinary language," or "Oxford" movement of analytic philosophy. Analytical philosophy was characterized by its belief that philosophical problems were usually caused by inattention to or misunderstandings of ordinary uses of language (Caton, 1963); hence, these problems can be resolved through consideration of the ordinary uses of the terms by which the relevant philosophical concepts are expressed. In fact, according to their perspectives of ordinary, there were two different schools in the movement of analytical philosophy. The logical positivists, represented by Moritz Schlick, Rudolf Carnap, Alfred Tarski etc., held that everyday language was not perfect, and thus should "be improved or replaced by an ideal, logical or artificial language" (Jiang, 2000: p. 198). They also argued that a sentence was meaningless unless it could be veri- 
fied. However, the ordinary language school held that human language was quite efficient and there should be a distinction between a sentence and its real meaning. From their perspective, a sentence could not be assigned truth values unless it was used in actual situations. J. Austin was one of the most important members of the ordinary language school. In order to combat the logical positivists, he wrote his famous book How to Do Things with Words in which he founded his famous Speech Act Theory.

He began the book by discovering a mistake through which many traditional philosophical perplexities have arisen, i.e. "the mistake of taking as straightforward statements of fact utterances which are either (in interesting non-grammatical ways) nonsensical or else intended as something quite different". (Austin, 2002: p. 3)

In his book Austin pointed out that for quite a long time, philosophers assume that the business of a "statement" can only be to "describe" some state of affairs, or to "state some facts", thus the statement is either true or false. In his recent years, Austin also noticed that some philosophers began to scrutinize those things which would have been traditionally accepted without question as "statement" with new care. There came the view that "a statement (of fact) ought to be "verifiable" and so "many statements are only what may be called pseudo-statements" (2002: p. 2). According to Kant, many statements are nothing but nonsense with unexceptional grammatical form. But there do exist some "fresh types of nonsense, unsystematic though their classification and mysterious though their explanation is too often allowed to remain, has done on the whole nothing but good" (2002: p. 2). Austin noticed that sometimes "to utter the sentence (in, of course, the appropriate circumstances) is not to describe my doing of what I should be said in so uttering to be doing or state that I am doing it: it is to do it" (2002: p. 6). These utterances cannot be judged by the criterion of whether they are true or false. Just because of the disability of philosophy in explaining the above statements, Austin introduced the two terms "constative" and "performative" and reclassified the so called "statements" into these two kinds.

\subsection{Constatives}

In his How to Do Things with Words, Austin pointed out that "it has come to be commonly held that many utterances which look like statements are either not intended at all, or only intended in part, to record or impact straightforward information about the facts" (2002: p. 2), he noticed that many seemingly descriptive statements do not serve to indicate some specially odd additionally feature in the reality reported, but "to indicate (not to report) the circumstances in which the statement is made or reservations to which it is subject or the way in which it is to be taken and the like" (2002: p. 3). Philosophers before would rather call these possibilities "descriptive" fallacy; but Austin argued that "descriptive" the word itself is special and not all true or false statements are descrip- 
tions. Hence the word "descriptive" is not a good name, he preferred to use the word "constative". Here we have some examples for constatives, e.g. "China is in Asia", "John has five children" or "France is hexagonal". About all these statements we may ask "Are they true or false". Obviously in order to answer these questions we need to compare the contents of these utterance (what is called proposition in philosophy) with the facts, if the former corresponds to the latter, they are true; if not, they are false. According to Austin all those utterances that have the property of being true or false are constatives.

\subsection{Performatives}

According to Austin, performative is the term that "indicates that the issuing of the utterance is the performing of an action-it is not normally thought of as just saying something" (2002: p. 6). The term "performative" is derived from "perform", the usual word with the noun "action". Though Austin found there are a number of terms that may suggest themselves like "contractual" ("I bet") or "declaratory" (I declare war), no term is wide enough to cover all classes of performative. Actually the term "operative" comes nearest to his "performtive", but it is used strictly by the lawyers. On account of the above reason, Austin himself invented the term "performative". Austin also provided the criteria of identifying those performatives (2002: p. 5)

1) they do not "describe" or "report" or constate anything at all, are not "true or false"; and

2) the uttering the sentence is, or is a part of, the doing of an action, which again would not normally be described as, or as "just", saying something.

In order to clarify his idea, Austin gave several examples in his book:

a) "I name this ship the Queen Elizabeth"-as uttered when smashing the bottle against the stem.

b) "I give and bequeath my watch to my brother"-as occurring in a will.

c) "I bet you sixpence it will rain tomorrow."

The performatives cannot be said to be "true" or "false" in that this kind of utterances is not issued to describe or to report some facts, but to do things. Let's take the sentence "I name this ship the Queen Elizabeth" for example, in saying that the speaker doesn't mean to describe or report something about the ship but to perform the act of naming the ship.

\subsection{Conditions for Happy Performatives: The Introduction of the Term "Felicities" and "Infelicities"}

Though performatives are not utterances which could be "true" or "false", they can be happy or unhappy. Austin held the opinion that performatives must be issued seriously by appropriate person under appropriate circumstances and also "it is very commonly necessary that either the speaker himself or other persons should also perform certain other actions, whether 'physical' or 'mental' actions or even acts of uttering further words" (2002: p. 8). In fact Austin gave six rules needed for giving a happy performative, as lists in the following (2002: pp. 
14-15)

(A. ${ }_{1}$ ) There must exist an accepted conventional procedure having a certain conventional effect, that procedure to include the uttering of certain words by certain persons in certain circumstances, and further

$\left(\mathrm{A}_{2}\right)$ the particular persons and circumstances in a given case must be appropriated for the invocation of the particular procedure invoked.

$\left(B_{._{1}}\right)$ The procedure must be executed by all participants both correctly and

(B..$_{2}$ ) completely.

$\left(\Gamma_{._{1}}\right)$ Where, as often, the procedure is designed for use by persons having certain thoughts or feelings, or for inauguration of certain consequential conduct on the part of any participant, then a person participating in and so invoking the procedure must in fact have those thoughts or feelings, and the participants must intend so to conduct themselves, and further

$\left(\Gamma_{{ }_{2}}\right)$ must actually so conduct themselves subsequently.

If a performative utterance is against any one (or more) of the above six rules (for detailed distinctions between the rules see Austin (2002: pp. 14-15), we may say that it is "Unhappy", and the things done by unhappy performatives are called "Infelicities"; (in his paper Performative-Constative 1958, Austin classified three kinds of unhappiness associated with the performative utterances: a) unhappy because of being "null and void", b) unhappy because of being issued insincerely, c) unhappy because of "breach of commitment".) On the contrary, if a performative utterance follows the rule, it is "happy", and the things done by them are "felicities".

Let's take one of the examples given by Austin to illustrate the happy performatives. For the utterance "I give and bequeath my watch to my brother", the conventional procedure might be that the legator must be very old or dying ( $\left.\mathrm{A}_{2}\right)$ and he must have a watch and he really wants to bequeath it to his brother $\left(\Gamma_{{ }_{1}}\right)$ he must also find or send for a lawyer $\left(\mathrm{A}_{2}\right)$, and the lawyer must witness the writing of the will by the legator or write it under the authorization of him. (B. $\left.{ }_{1}\right)$ $\left(B_{.2}\right)$ Thus the conventional effect of this performative is the legal validity of the will. $\left(\mathrm{A}_{._{1}}\right)$ and the watch will be given to the legator's brother after the legator's death. $\left(\Gamma_{\cdot_{2}}\right)$. Under such an analysis, the utterance will be happy, but if the legator sins against any one (or more) of these six rules, his performative will be (in one way or another) unhappy.

\section{The Significance and Austin's Self-Criticism of the Distinction between Constatives and Performatives}

\subsection{The Significance of the Distinction}

As we all know the study of meaning is always one of the important topics in linguistics. However since the linguist turn in philosophy, before Austin put forward his speech act theory, the study of meaning was still restricted in the category of semantics. Linguists and philosophers focused on the study of the meanings of the sentences and the words and also the truth value of the state- 
ment. So the meaning studied in linguistics is the cognitive meaning of a statement instead of its meaning affected by the context. That is to say, for the traditional semantics, the truth value is the only criterion to judge the meaning of a statement: if the description of a statement accords with reality, the statement is said to have truth value and it is a normal statement; if the description of it does not accord with reality, it does not have truth value, and it is a pseudo-statement. For example, somebody says "It is cold here", logically and semantically there are two possibilities for the meaning of this statement: if it is really cold in the room, the statement is true; if the room is not cold, the statement is false. However the truth value may not cover the whole meaning that the speaker wants to express. It might be some kind of "request", in saying that the speaker means to ask the listener to fetch some warming-up instruments; and also it might be some kind of "invitation", in saying that the speaker means to invite the listener to a comparatively warm room; there might be some other possibilities, too (Zhang, 1998). From the above example, we clearly see that the logic-semantics cannot grasp all the meanings of the statement. Besides there are some sentences which do not have the properties of being true or false, e.g. "I promise to pay you tomorrow", it is only a promise instead of the description of a fact or a state. In this way the distinction between constative and performative provides us with a new perspective on the meaning of utterance.

It was from the distinction between constative and performative that Austin began his famous speech act theory. The theory, which was developed by John Searle and some other philosophers, has now become one of the greatest fundamental theories in pragmatics. Many philosophers evaluate Austin highly, the famous German philosopher W. Stegmuller once commented on Austin's theory in his book that it was a shame for the people who studied language from any aspect in the past 2500 years that they did not find that we can use language to perform various things (Stegmüller, 1980: p. 66). Scholars holding the same opinion about Austin's theory include Gale (1970), Jacobsen (1971) and Jiang (2003).

\subsection{Austin's Self-Criticism}

What must be mentioned at the end of the paper is Austin's self-criticism towards his distinction between constative and performative. Though Austin spent seven chapters in his book How to Do Things with Words in analyzing performative, he later confessed that "that there is no purely verbal criterion by which to distinguish the performative from the constative utterance, and the constative is liable to the same unhappiness as the performative" (2002). In a word, there is no clear cut between the two kinds of utterances. Austin said so because soon he found that the six felicity conditions suggested by him only apply to some cases. We do have some other cases in which we produce a performative without the need of a conventional procedure. For example in order to make a promise, we can just say either "I promise" or "I swear", yet no strict procedure is needed. On 
the other hand, some of the constatives may be also said to be infelicitous. "The present king of France is bald" is infelicitous in the same way as "I bequeath my watch to my brother" said by somebody without a watch. They both presuppose the existence of something, which does not actually exist. And also when people are making statements they must also have requisite thoughts, feelings and intentions. They cannot say "All the guests are French, and some of them aren't".

Austin also explored the possibility of separating performatives from constatives on grammatical and lexical criteria. But both attempts turned out to be in vain, and Austin found that all sentences can be used to do things. The result was that Austin had to abandon his distinction between performatives and constatives (Hu, 2001: pp. 246-249).

The abandonment of the distinction between constative and performative symbolizes Austin's fresh start on the problem and considered it from the ground up again, i.e. in what sense to say something is to do something, and thus he developed a more general theory of the speech act.

\section{Acknowledgements}

This paper is under the social service project of "A Study of Publicity Promotion and Training of Employee's Foreign Language Skills (Project No. 20200929)" and the project of "Reform of English Major Teaching under the Perspective of Need Analysis Theory (Project No. 2014010216)", both of which are sponsored by Baoding University. I am deeply indebted to all the team members, who offered invaluable advice and comments.

\section{Conflicts of Interest}

The authors declare no conflicts of interest regarding the publication of this paper.

\section{References}

Austin, J. L. (2002). How to Do Things with Words. Beijing: Foreign Language Teaching and Research Press.

Caton, C. (1963). Philosophy and Ordinary Language. Urbana: University of Illinois Press.

Gale, R. M. (1970). Do Performative Utterances Have Any Constative Function. The Journal of Philosophy, 67, 117-121.

Hu, Z. (2001). Linguistics. A Course Book(2nd ed.). Beijing: Peking University Press.

Jacobsen, K. H. (1971). How to Make the Distinction Between Constative and Performative Utterance. The Philosophical Quarterly, 21, 357-360.

Jiang, W. (2000). Pragmatics: Theories and Applications. Beijing: Peking University Press. Jiang, W. (2003). Contemporary Pragmatics. Beijing: Peking University Press.

Stegmüller, W. (1980). Neue Wege der Wissenschaftsphilosophie (German Edition). Berlin: Springer.

Zhang, X. (1998). Derrida's Deconstruction of Austin's Speech Act Theory. Foreign Literatures, No. 3, 4-9. 